\title{
Bioactive Compounds and Anti-Microbial Activity of Ventilago denticulata Fruits and its Toxicity to Artemia salina L
}

\section{Adya Anindita Dash and Sanjeet Kumar*}

Biodiversity and Conservation Lab, Ambika Prasad Research Foundation, Odisha, India

*Corresponding Author: Sanjeet Kumar, Biodiversity and Conservation Lab, Ambika Prasad Research Foundation, Odisha, India.
Received: March 02, 2020

Published: March 20, 2020

(C) All rights are reserved by Adya Anindita

Dash and Sanjeet Kumar.

\begin{abstract}
Despite number of allopathic medicines, the infectious diseases are burning issues due to Aniti-microbial Resistance (AMR). Therefore, need to screen new source from biowealth. Keeping this in view, an attempt has been made to qualitative analysis of bioactive compounds; evaluate the antibacterial activity against Gram positive bacteria (Streptococcus pyogens) and estimation of toxicity to Artemia salina. The results revealed that fruit extracts rich with phenolic compounds. The MIC (Minimum Inhibitory Concentration) was done using Broth Dilution Assay and it was observed that methanol extract of Ventilago denticulata (Fruits) showed an excellent activity against S. pyogens. It was noted that methanol extract showed $80 \%$ inhibition after 24 hrs against brine. The present study highlights the antibacterial potential of common plant of Odisha and recommended to isolate the responsible compound(s) to formulate new drugs to fight against AMR.
\end{abstract}

Keywords: Wild Plants; Gram-Positive Bacteria; Anti-Microbial Resistance

Even since ancient times, in search for rescue for their disease the people looked for drugs in nature [1]. Medicinal plants are great importance to the health of individuals and communities as well. The medicinal value of plants lies in some biochemical substances present in them that produce a definite physiological action on the human body [2]. The use of herbal medicine for the treatment of diseases and infections is an age old practices. The world health organization supports the use of traditional medicines provided they are proven to be efficacious and safe. In developing countries, a large number of people live in extreme poverty and many of them are suffering and dying for want of safe water and medicine, they have no alternatives for primary health care [3]. Therefore, it is need to use medicinal plants as alternative to medicines in the absence of primary health. More so herbal medicines have received much attention as source of bioactive compounds, since they are considered as time tested and relatively safe for human use and also environment friendly. Therefore, there is the need to search for more and more herbal medicinal plants with an aim to validate the ethno-medicinal use and subsequently the isolation and characterization of compounds in them which can be added to the potential list of drugs [4]. Plants and herbs were introduced as a potential source of natural antioxidants in recent years. Bioactive compounds of plants and herbs like flavonoids, tannins etc. esters can provide antioxidant properties and beneficial effects like antimutagenic, anticarcinogenic, and cardio protective activities [5]. Ventilago denticulata Wild. (Figure 1.1) commonly called the Red Creeper of the family Rhamnaceae, is an extensively branched, woody climber with hanging branches. Leaves ovate-oblong to elliptic-oblong, irregularly crenate-serrate or entire, acute, acuminate or sub acute, glabrous or pubescent above, pubescent beneath, secondary nerves often 4-5. Panicles are densely pubescent. Fruit are samaroid. It is a native of India and distributed in China, Myanmar and fairly common in mixed forests. The stem and root bark of this plant is a source of red dye 'Ventilagin' which is used for color- 
ing cotton, wool and tasar. Stem bark when powdered and mixed with sesame oil, can be externally applied to treat skin diseases and sprains. Root bark is used for atonic dyspepsia, mild fever and debility. Sap is used for the treatment of deafness. The ethanolic extract of plant also shows anti-inflammatory activity. The plant is rich in many pharmaceutical active ingredients [6]. The stem bark contains friedelin and several anthraquinones. The root contains anthraquinones, ventinones A and B. Major Constituents of the root bark are emodin, its glucoside and corresponding analogues, ventiloquinones [7]. The fruit, leaves and stem give lupeol, betasitosterol and its glucoside. Literature survey revealed that the fruit extract has not yet been screened for antimicrobial activity. Therefore the objective of the current work was to evaluate the antimicrobial activity and its toxicity to Artemia salina L. and the presence of bioactive compounds. Ventilago denticulata fruits were collected from the village near Chandaka Dampara wildlife Sanctuary, the Jhumka dam area, which is a minor irrigation project near to sanctuary boundary. The collected fruit materials from plants were washed thoroughly by tap water followed by distilled water twice and then oven dried. The dried materials were crushed to powder with mechanical device and were kept in an air tight container for qualitative analysis of bioactive compounds. Qualitative phytochemical analysis was done using soxhlet method (Figure 1.2) [8]. The Brine shrimp assay was carried out according to the principle described by Meyer., et al. (1982) [9] and Krishnaraju., et al. (2005) [10]. Solvent was extracted by using methanol. Filtrates were dried and concentrated to get semi solid mass. All the phytochemical assays were conducted using same extract. The brine shrimp lethality assay (BSLA) has been routinely in the primary screening of the crude extracts, to assess the toxicity towards brine shrimp, which might provide an indication of possible cytotoxic properties of the test materials. Brine shrimp nauplii have been previously utilized in various bioassay systems [11]. It is a typical primitive arthropod with segmented body to which is attached broad leaf-like appendages. The body usually consists of 19 segments, the first 11 of which have pairs of appendages; the next two which are often fused together carry the reproductive organs, and the last segments lead to the tail. The total length is about $4 \mathrm{~mm}$ [12]. It is found suitable as a "standard" organism in toxicologi- cal assays, despite the recognition that it is too robust an organism to be a sensitive indicator species [12]. Shrimp eggs were kept for hatching in $6 \%$ normal saline for 18 hours. Plant extract obtained following the above protocol were subjected to motility assay. Readings were taken every hour up to 6hours and later at 24 hours. Motility parameters such as, +4 indicate high motile, +3 indicate motile, +2 indicate sluggish and +1 indicate slow. Antibacterial activity was done as per standard method of Nayak., et al. (2015) [13]. The phytochemical results revealed that fruits possess saponin, tannin, phenolic compounds, flavonoids and also rich with primary metabolites like carbohydrate, lipid, protein, starch and sucrose (Table 1). The DMSO was taken as standard solvent for dissolving extract and it was observed that 5\% DMSO is suitable for brine shrimp assay (Table 2). The toxicity of methanol extract (fruits) was done using brine shrimp assay and it was observed that maximum inhibition was noted in methanol extract (Table 3 and 4). The inhibition and phytochemical assay revealed that the fruits might be used as anticancer agent $[14,15]$. The MIC showed that the fruits might be used against skin infection (Figure 1.3). The present study highlights the importance of wild plants as potent medicinal agent and would be the suitable source for screening of new compounds to fight against anti-microbial resistance (Figure 1).

\begin{tabular}{|l|c|}
\hline Bioactive compounds & Detection \\
\hline Saponin & + \\
\hline Tannin & ++ \\
\hline Phenolic compounds & +++ \\
\hline Flavonoids & -ve \\
\hline Terpenoids & -ve \\
\hline Reducing sugar & + \\
\hline Amino acid & + \\
\hline Lipid & + \\
\hline Protein & $=$ \\
\hline Carbohydrate & + \\
\hline Starch & + \\
\hline Sucrose & + \\
\hline
\end{tabular}

Table 1: Phytochemical screening of Ventilago denticulata fruits (+: Present; ++: Mild: +++: Rich). 


\begin{tabular}{|c|c|c|c|c|c|c|c|c|}
\hline \multirow{2}{*}{ DMSO concentration } & \multicolumn{8}{|c|}{ Time } \\
\hline & $10 \mathrm{M}$ & $30 \mathrm{M}$ & $60 \mathrm{M}$ & $1 \mathrm{hr}$ & $2 \mathrm{hr}$ & $3 \mathrm{hr}$ & $24 \mathrm{hr}$ & $\%$ of inhibition \\
\hline $20 \%$ & +4 & +4 & +4 & +4 & +4 & +4 & 0 & $100 \%$ \\
\hline $15 \%$ & +4 & +4 & +4 & +4 & +4 & +4 & 0 & $100 \%$ \\
\hline $10 \%$ & +4 & +4 & +4 & +4 & +4 & +4 & 0 & $100 \%$ \\
\hline $05 \%$ & +4 & +4 & +4 & +4 & +4 & +4 & +4 & $0 \%$ \\
\hline $04 \%$ & +4 & +4 & +4 & +4 & +4 & +4 & +4 & $0 \%$ \\
\hline $03 \%$ & +4 & +4 & +4 & +4 & +4 & +4 & +4 & $0 \%$ \\
\hline $02 \%$ & +4 & +4 & +4 & +4 & +4 & +4 & +4 & $0 \%$ \\
\hline $01 \%$ & +4 & +4 & +4 & +4 & +4 & +4 & +4 & $0 \%$ \\
\hline
\end{tabular}

Table 2: Standardization of DMSO for Brine Shrimp Assay.

( +4 indicate high motile; +3 indicate motile; +2 indicate sluggish; +1 indicate slow; 0 indicate death).

\begin{tabular}{|c|c|c|c|c|c|c|c|c|c|c|c|}
\hline \multirow{2}{*}{\multicolumn{2}{|c|}{ Sample }} & \multicolumn{10}{|c|}{ Time } \\
\hline & & \multirow{2}{*}{$\begin{array}{c}10 \mathrm{M} \\
+4\end{array}$} & \multirow{2}{*}{$\begin{array}{c}20 \mathrm{M} \\
+4\end{array}$} & \multirow{2}{*}{$\begin{array}{c}30 \mathrm{M} \\
+4 \\
\end{array}$} & \multirow{2}{*}{$\begin{array}{c}60 \mathrm{M} \\
+4 \\
\end{array}$} & \multirow{2}{*}{$\begin{array}{r}2 \mathrm{hr} \\
+4\end{array}$} & \multirow{2}{*}{$\begin{array}{l}3 \mathbf{h r} \\
+4\end{array}$} & \multirow{2}{*}{$\begin{array}{r}4 \mathrm{hr} \\
+4\end{array}$} & \multirow{2}{*}{$\begin{array}{c}18 \mathrm{hr} \\
+4\end{array}$} & \multirow{2}{*}{$\begin{array}{c}24 \mathrm{hr} \\
+3\end{array}$} & \multirow{2}{*}{$\begin{array}{c}\text { \% of inhibition } \\
40 \% \\
\end{array}$} \\
\hline Methanol extract & $100 \mathrm{gm} / \mathrm{ml}$ & & & & & & & & & & \\
\hline & $200 \mathrm{gm} / \mathrm{ml}$ & +4 & +4 & +4 & +4 & +4 & +4 & +4 & +3 & +3 & $40 \%$ \\
\hline & $300 \mathrm{gm} / \mathrm{ml}$ & +4 & +4 & +4 & +4 & +4 & +4 & +4 & +3 & +2 & $60 \%$ \\
\hline & $400 \mathrm{gm} / \mathrm{ml}$ & +4 & +4 & +4 & +4 & +4 & +4 & +4 & +1 & +1 & $80 \%$ \\
\hline & $500 \mathrm{gm} / \mathrm{ml}$ & +4 & +4 & +4 & +4 & +4 & +4 & +4 & +1 & +1 & $80 \%$ \\
\hline \multicolumn{2}{|l|}{$5 \%$ DMSO } & +4 & +4 & +4 & +4 & +4 & +4 & +4 & +4 & +4 & $0 \%$ \\
\hline \multicolumn{2}{|l|}{ Brine water } & +4 & +4 & +4 & +4 & +4 & +4 & +4 & +4 & +4 & $0 \%$ \\
\hline \multicolumn{2}{|l|}{ Distilled water } & +4 & +4 & +4 & +4 & +4 & +4 & +4 & +4 & +4 & $0 \%$ \\
\hline
\end{tabular}

Table 3: Toxicity of methanol extract of fruits of Ventilago denticulata against Artemia salina L.

(M: Minutes).

\begin{tabular}{|l|l|c|}
\hline Sample & Concentration & Inhibition \\
\hline Methanol extract & $100 \mathrm{mg} / \mathrm{ml}$ & Growth of Bacteria \\
\cline { 2 - 3 } & $200 \mathrm{mg} / \mathrm{ml}$ & Growth of Bacteria \\
\cline { 2 - 3 } & $300 \mathrm{mg} / \mathrm{ml}$ & Growth of Bacteria \\
\cline { 2 - 3 } & $400 \mathrm{mg} / \mathrm{ml}$ & Growth of Bacteria \\
\cline { 2 - 3 } & $500 \mathrm{mg} / \mathrm{ml}$ & No growth detected \\
\hline Broth & No growth detected \\
\hline Inoculum & Growth of Bacteria \\
\hline DMSO & Growth of Bacteria \\
\hline
\end{tabular}

Table 4: MIC (Minimum inhibitory concentration) of methanol fruit extract of Ventilago denticulata against Streptococcus pyogens.

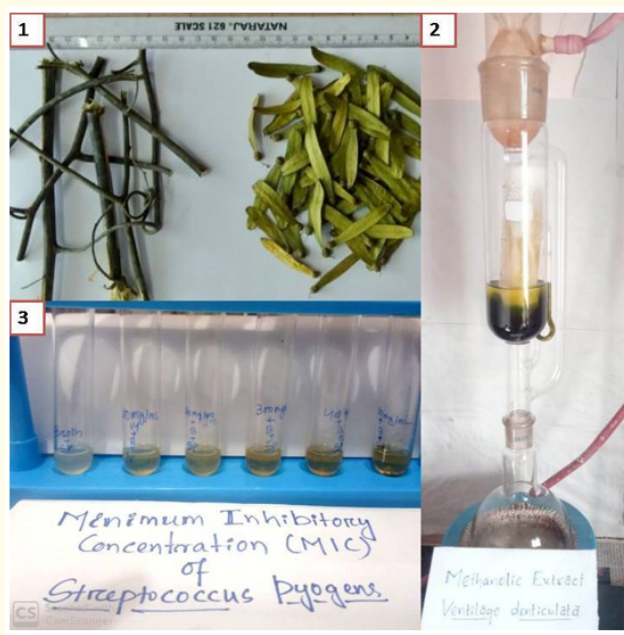

Figure 1: Collection and experimental works, 1) Fruits and stems of V. denticulata, 2) Soxhlet extraction of fruits of V. denticu-

lata, 3) MIC of methanol extract of fruits of V. denticulate. 


\section{Bibliography}

1. Petrovska BB. "Historical review of medicinal plants". Pharmacognosy Reviews 6.11 (2012): 1-5.

2. Edeoga HO., et al. "Phytochemical Constituents of some Nigerian Medicinal plants". African Journal of Biotechnology 4.7 (2005): 685-688.

3. World Health Organization (WHO). Chronicle 39 (1985): 5159.

4. Kumar S., et al. "Ethnobotany and bioactive compounds in leaf of Bixa orellana L. and its toxicity to Artemia salina L". Plant Science Research 34.1-2 (2012): 93-96.

5. Farahmandfar R., et al. "Bioactive compounds, antioxidant and antimicrobial activities of Arum maculatum leaves extracts as affected by various solvents and extraction methods". Food Science and Nutrition (2019).

6. Preeti M., et al. "In Vitro Anthelminthic activities of whole plant of Ventilago denticulata Wild. Against Pheretima postuma". Asian Journal of Pharmaceutical and Clinical Research 5.3 (2012): 200-201.

7. Havsteen B. "Flavonoids, a class of natural products of high pharmacological potency". Biochemical Pharmacology 32 (1983):1141-1148.

8. Harbone JB. Phytochemical methods. Chapman and Hall, Ltd". London (1973).

9. Meyer BN., et al. "Brine shrimp: A convenient general bioassay for active plant constituents". Planta Medica 45 (1982): 31-34.

10. Krishnaraju AV., et al. "Assessment of bioactivity of Indian Medicinal plants using brine shrimp lethality assay". International Journal of Applied Science and Engineering 3.2 (2005): 125-134.

11. McLaughlin JL., et al. "Simple Bench-Top Bioassays (Brine Shrimp and Potato Discs) for the Discovery of Plant Antitumor Compounds". Department of Medicinal Chemistry and Pharmacognosy, School of Pharmacy and Pharmacal Sciences, Purdue University, West Lafayette (1991).

12. Criel GRJ and Macrae HT. "Artemia morphology and structure. Biology of Aquatic Organisms. Kluwer academic Publishers". The Netherlands (2002).
13. Nayak S., et al. "Design and synthesis of (E)-4-(2H-Chromen3-yl) but-3-en-2-ones and evaluation of their In vitro antimicrobial activity". Letters in organic Chemistry 12 (2015): 1-7.

14. Paudel B., et al. "Estimation of antioxidant, antimicrobial activity and brine shrimp toxicity of plants collected from Oymyakon region of the Republic of Sakha (Yakutia), Russia". Biological Research 47.1 (2014): 1-10.

15. Pongjanta A., et al. Antioxidant activity and cytotoxic Effect of Ventilago denticulata Wild leaves extracts 1 (2016): 51-57.

\section{Assets from publication with us}

- Prompt Acknowledgement after receiving the article

- Thorough Double blinded peer review

- Rapid Publication

- Issue of Publication Certificate

- High visibility of your Published work

Website: www.actascientific.com/

Submit Article: www.actascientific.com/submission.php

Email us: editor@actascientific.com

Contact us: +919182824667 